\title{
Financial Management Professional Teaching Reform Research
}

\author{
Yan-Saiyan \\ Hunan Institute of Information Technology ,China
}

Keywords: financial management professional teaching reform and innovation system

\begin{abstract}
: in this paper, using the practical teaching theory analyzes the present situation of financial management teaching, find out the existing problems and puts forward establishing practical teaching system, the simulation practice teaching system and the field practice teaching system of teaching reform train of thought.
\end{abstract}

\section{Introduction}

As the economy management department established in comprehensive universities, the financial management specialty has become each department of economic management of large, in the comprehensive universities in hunan province, the financial management professional enrollment increasing, by the first 2 to 3 class, even many schools have a grade five or six class. Recruit students object mostly girls, boys are relatively few. The phenomenon of increased economic management graduate employment pressures. For financial management major, we think there are three kinds of cultivating object can be to graduation. Part of the result good students upgrade admitted to graduate students, some students admitted to civil servants, the final results of most of the students is to large and medium-sized enterprises in the society. So, we put this to use, and the teaching process to practical teaching, cultivating students' ability to adapt to society, knowledge and skills. Here, and we in the financial management of the teaching experience for many years, to do some simple practical teaching system, to the universities financial management professional teaching workers to share.

Famous education experts Rousseau once advocated for practice teaching in the teaching idea, think students learning effect is the worst in is, in practice to multiple effect in the process of learning. Practice teaching is an important part in financial management professional teaching link, is an important part of the successful realization of quality education in colleges and universities, to develop students' innovative spirit and cultivating practice ability. Many colleges and universities in the financial management professional course teaching is used to complete theory course teaching, with a very short time in the training room or a classroom for students to focus on simulation experiment, the last before graduation internship arrangements to unit a short time. This model, the former two section in the school, at the end of the link may have a problem. Financial management professional students go out practice, some companies don't want to accept, some units even if accepted, mostly for students to have a closer look at the working process of the enterprise, don't let the student to carry on the concrete accounting practice; Students themselves because of individual differences, some students in a short time, it's impossible to be comprehensive financial management professional practice. So to the last link of practice often become a mere formality, students take a internship certificate is made worse. 


\section{The financial management problems existing in the professional practical teaching (a) lack of practical experience of teachers}

With the expansion of college financial management professional students, the lack of professional teachers is an important issue, because it is undergraduate course education, so financial management must have a master's degree of professional teachers, the teachers are just graduated from school took to the podium, mastered the rich theoretical knowledge, but the teacher did not take part in social practice, lack of practical experience, teaching only to teaching material as the center, with the theory to analyze and solve problems. So that the financial management practice teaching is difficult to achieve the desired effect. To cultivate and improve the students' innovation and practical ability, requires that teachers should not only have good financial management theory knowledge, still should have rich Practice ability.

Financial management is a practical course, but in financial management concepts and ideas that are still not fully out of the mould of exam-oriented education theory, practice, emphasizes the financial management theoretical knowledge of systemic sex, not fully realize the importance of practical teaching, leading to lack of equipment, lack of management practice teaching teachers, lack of stable field, thereby greatly influence the teaching quality of financial management, the personnel to the satisfaction of the society. Financial management teaching should be done through multiple links and multiple levels of practice, through the practice teaching of the overall design, clear the purpose of each section of a real, contents and requirements, make different link connect with each other, phase Pick up, form an organic whole, and thus through training, to improve students' skills. But at present, financial management practice teaching lack of organic connection, single room simulation exercises are easy, off-campus practice base practice, social practice investigation organization, practice teaching content and every link itself

Added, narrow, there is no perfect the financial management practice of the teaching material, effectively improve students' comprehensive ability to apply the knowledge and analytical ability to solve practical problems.

The financial management of practice teaching, and certain gap with the real financial management practice, the lack of real business of stereo feeling, students can only pass word to understand the case, through the teacher's explanation and guide the student to complete the industry to the theoretical knowledge is learning and I do not know why, the students felt a hindrance when contact with practice, the theory cannot very good guidance in practice.

The practice of the scientific and perfect teaching method system is one of the important means of training high-quality financial talents. Form of teaching at present is mainly teachers teach, supplemented by the verification of the case study, the students learned later stay in a set of data, on the basis of a standard answer, decision-making ability and comprehensive quality has not been improved. Financial management teaching from the teaching means, still mostly in "a piece of chalk + a notes", on the condition of not to apply modern high-tech means such as computer network teaching, which leads to the improvement of teaching efficiency and teaching level is not obvious.

In order to effectively improve students' ability and the ability to solve practical problems, in the financial management of teaching arrangements with financial management practice and graduation practice, but the two most of the practice teaching link in the seventh and eighth period of the term, because now the employment situation is grim, most students have such "opportunities" to look for employment units, the interview, no desire, as for the school appraisal table, asked to complete an internship report and internship students to made, so that financial management practice and graduation practice become a mere formality, monitoring system failure. 


\section{We believe that the financial management specialty practical teaching system includes the following several aspects:}

Financial management professional curriculum should pay attention to practical teaching, first of all, when in the course of setting should pay attention to practicality, scientific. Financial management professional can set some professional basic course of department of economic management, such as "economics", "management" and so on, but should not set up the professional strong "organizational behavior" journal of human resource management courses, and the foundation courses on the selection of teaching materials should also be easy to understand, is not too big. Financial management professional students toward society is engaged in financial work, so the accountant from job seniority card is each big colleges and universities for students before graduation will be one of the documents, some colleges and universities require a assistant accountant certificate. So on curriculum setting, when the first year of college in addition to setting the accumulation of basic course, can set up some "basic accounting" and "computerized accounting" and "law", after the students can directly enter oneself for an examination the accountant card, sophomore can set the "financial management", "intermediate financial accounting, cost accounting, tax, finance, finance and the nonprofit organization accounting, after the students can enter oneself for an examination, assistant accountant, the big three can set up the financial statement analysis, senior financial accounting, tax planning, senior financial management, capital operation, such as" risk management ", "science of auditing courses, for qualified can enter oneself for an examination and the certified public accountants, certified senior year can set up the international financial management, international accounting, international finance, securities and futures, learn some knowledge and finance with the international convergence of some knowledge of the cross, to prepare for field work. Then after these courses, must be reasonable choice materials. Textbooks for teaching and practice of the version, it is best to each chapter after the problem sets are all practice problem sets, rather than purely theoretical problem. Knowledge in the classroom lessons learned after digestion.

Financial management professional practical teaching can also reflect on the simulation training system. From freshman to junior year, students can use this way in school teaching. Simulation training purpose is to let students work in the financial management in the simulation of enterprise environment, so as to put this to use, and to cultivate students ability to apply social as early as possible. Simulation training as a kind of practical teaching mode, to attract the interest of students, improve the students' study enthusiasm, improve the initiative of the teachers' teaching. Simulation training brings a new mode of teaching, enrich the classroom teaching, make students and teachers can be in a new way of thinking to realize, realize enterprise financial management activities. The design of the simulation training can generally in stages according to the grade. First of all, freshman learning basis of accounting and computerized accounting. Basis of accounting for this course, we can give it to establish the simulation training is manual simulation training. Hand simulation training is a full simulation of internships, school as much as possible to build a manual simulation training room imitating enterprise working environment, management environment. Buy used a series of enterprise accounting office supplies, dedicated to proof of charge to an account, binding machine, paper statements, paper clips, paste list. Training material to had better choose a real real economic business of manufacturing enterprise for a month, the students set up cashier personnel division, general ledger accounting, detailed accounting, reporting and the overall requirements of distribution of internship and daily requirements. Generally a week, method to prepare accounts, according to the books of the preparation of proof of charge to an account according to the business. According to proof of charge to an account registration cash and bank 
deposit journal on a daily basis. According to the original vouchers and accounting voucher register subsidiary ledger. Prepare the course summary table on a regular basis. Its method is according to proof of charge to an account, follow the same course the amount of the debits and credits to collect respectively, after the trial balance, which is registered. According to the course summary table register general ledger on a regular basis. Check, check and prepare the trial balance. According to the books record prepare balance sheet and income statement for this month. The manual practice allows students to apply accounting principle of theory class to go to school to practice, grasp the subscription, make account book, calculation report, summarize the operation method of accounting files, can also be better to let the students familiar with the working process of the enterprise, can adapt to the society after graduation. The computerized accounting accounting information can also be a systematized under the background of a professional course, the course of the simulation effect is stronger than the manual practice. School according to the scale of the students with practical training room, training room generally including students and teachers, and purchase of the software. Can be done in the training room, "basic accounting", "management accounting", "financial accounting", "financial management", "cost accounting", and many other training courses. Training content must be up to the present enterprise working environment, with the rapid development of information technology, basic popularization of computerized accounting work, so this course ten students must master a curriculum. Room equipped with including the selection of PC and server, including the selection of the software. Is generally selected for software YONGYOU、JINDIE and other common office software. The software version can choose medium above, training content include: students in practice are in complete initialization of system management; General ledger system initialization and processing of the business, including documents drawn up, auditing, accounting, custom transfer, check, check out; UFO meter computerized training for financial management professional accounting computerization course learning of students, use the market mainstream such as uf financial software build accounting operation platform. Can complete all the courses of computerized training, the training content is mainly system initialization Settings, general ledger accounting treatment, UFO reports management, procurement management, salary accounting treatment, etc. Through this training, students can be familiar with accounting software operation skill, familiar with computerized accounting information system of the whole process of data, so that the students in the operation of the computerized accounting skills as to meet the requirement of accounting computerization junior staff training. The accounting computerization practice integration teaching method, teaching, learning and doing. Shall be the responsibility of the relevant professional teacher training arrangements and organizational work. This greatly enhances the students' perceptual knowledge in accounting computerization operation, to cultivate the students' professional practice ability, for students' graduation practice laid a good foundation. Secondly, in the sophomore year, students can be arranged for the financial management of ERP training courses. This practice is more virtual enterprises, through the electronic sand table simulation multiple enterprise production and business operation 6 years, every enterprise set up the CEO position, CSO, COO job, CFO, CMO, job, work task, complete enterprise management provide a training ground for students to enterprise management, cultivate students' comprehensive ability to run a business; Virtual enterprise finance department, each department set up the financial director, director of accounting, accountant and cashier main jobs. Simulation of the finance department of the basic configuration for the computer, financial software, a set of accounting data and other financial tools; Can let students perceptual knowledge role in economic management and financial management work flow, better learning knowledge in financial management. In addition, you can provide a good training for students to 
attend the ERP entrepreneurship competition and the competition area.

Financial management of the students in the freshman and sophomore, junior year summer vacation to the enterprise to the field work. Although many units will not accept students worked as an intern in the financial department, but we can choose some university-enterprise cooperation unit in the name of the school. And students can be a post of staff to take an intern manner, this requires our careful consideration when choosing the cooperative enterprise. We can choose as training system in the field unit from the following several aspects to consider:

The first firm, such as certified public accountants, certified tax accountant firm, real estate appraisal firm, the unit's business is more, need more financial personnel also corresponding. Certified public accountants of the scope of business includes: financial audit report issued for each big enterprise, each big unit of economic responsibility audit, issue a capital verification report, the annual inspection report issued by, for small businesses, bookkeeping agency work. Firm's business scope includes: certified for each big unit to provide tax consulting, for each big unit issued by tax statements, tax work, small business bookkeeping agency work. Real estate appraisal firm's business scope includes: real estate mortgage formalities for the enterprise and individual, issue a real estate appraisal report. Students can follow the business personnel in and out of each big enterprise, learn various business skills. These business ability, strengthen students' practical ability.

The second choice as university-enterprise cooperation unit manufacturing enterprises. Manufacturing enterprise business process comprehensive, starting from the raising of capital, after the purchasing of raw materials, product research and development, product sales, to the capital's exit and the final part is the settlement and distribution of profits. Enterprise in each link of allocation and utilization of human, financial, and each link of financial activities and financial relationship is the key point of contact and learning. Students in the university in grade one and grade two learning financial knowledge is basically to simulate manufacturing enterprise, so it's easy to accept the social knowledge and the ability to apply. Schools should be sent and the enterprise coordination communication, try to allow students to a top of a post in practice, it made students have a strong ability to adapt to society.

Graduation practice. Every school to cultivate the talents will eventually go social, so before graduation year should arrange for a term of not less than 90 days of the graduation internship.

\section{Summary}

Above all, the reform teaching system of financial management if we can in practical teaching as the center, supplemented by simulation training system, training system, field, cultivate the students will be able to better and faster to adapt to the society, serve the society.

\section{References}

[1] Minghui Wang,Chaozhi Zhu.Research on the training mode of financial management talents based on employment orientation. Journal of Hubei Radio\&Television University . 2013

[2] Zhongzhi Yang.Thinking about the specialty construction of accounting and financial management in Colleges and Universities. Communication of Finance and Accounting . 2013

[3] Wanggui Su.Some problems about financial management professional construction. Accounting Research . 2010

[4] Shihui Li.Exploration on the training mode of undergraduate financial management major based on the new financial environment. Modern University Education . 2009 